\title{
Evolution of soluble solid content and evaporation rate curves during the manufacture of dulce de leche (dl)
}

\author{
Júlia d'Almeida FRANCISQUINI ${ }^{1}$ João Pablo Fortes PEREIRA ${ }^{1}$, Michele da Silva PINTO $^{1}$, \\ Antônio Fernandes CARVALHO ${ }^{1}$, Ítalo Tuler PERRONE ${ }^{1 *}$, Paulo Henrique da Fonseca da SILVA ${ }^{2}$
}

\begin{abstract}
Dulce de leche is an evaporated dairy product that can be manufactured in different types of pots or pans. The manufacturing endpoint for dulce de leche can be determined by measuring the soluble solids content. We investigated the evaporation rates and the evaporative capacity of atmospheric pressure evaporators (pans) during the manufacture of dulce de leche. During manufacturing, four different formulations were subjected to soluble solids content determination by refractometry. In addition, the mass balance was used to determine the yield and evaporation rate. A low coefficient of variation and amplitude was found for soluble solids content, indicating standardization and uniformity during fabrication. We also observed a gradual increase in the latter throughout manufacture, without significant differences between the times. The evaporated water mass rate and its respective equation allow to reproduce the same characteristics of the experimental product in experimental and industrial production of dulce de leche.
\end{abstract}

Keywords: dairy products; evaporation; food processing aspects.

Practical Application: In Brazil there is an expressive commercialization and production of dairy products at an industrial level. Dehydrated dairy appears to be one of the main formulations. With this, the knowledge of the rate of evaporation of mass and the evaporative capacity of atmospheric pressure evaporators becomes of relevance for the dairy sector, although it is an area still little explored, since it can help in the improvement of the quality control and standardization of the food elaborate.

\section{Introduction}

Evaporation of dairy liquids is an important step in the dairy industry. Sweetened condensed milk, dulce de leche (DL), and evaporated milk are the main dairy products obtained by evaporation, as well as dairy powder products (Schuck et al., 2016; Silveira et al., 2015; Silva et al., 2015; Silveira et al., 2013). The concentration operation strongly modifies the product's physicochemical conditions, negatively impacting the concentrate as well as the process (Tanguy et al., 2016). Lactose crystallization, Maillard reaction, and increase in viscosity are consequences of the heating and of the concentration of the solids accompanying the milk evaporation (Arena et al., 2017; Stephani et al., 2015; Silva et al., 2015; Souza et al., 2015).

DL can be made in pots (evaporator at atmospheric pressure) by batch processing, in pans continuously, in vacuum evaporators, or using the vacuum evaporator and the pan. The pan usually has a stainless steel inner jacket and an outer jacket for steam inlet, being the heat exchanger mostly used in the manufacture of this product (Perrone, 2007).

The evaporation rate during dulce de leche production could be mathematical modeling by second degree equations.
This mathematical approach was established by Silva et al. (2013) during dulce de leche production obtained by mixtures of milk and whey.

During milk and whey evaporation only water is removed and the total amount of solids is transferred directly to the concentrated product. In this sense, the ratio between the total solids mass and the percentage of solids in the final product allows determine the mass of the concentrated product after evaporation. This general equation is decribed in Stephani \& Perrone (2012).

The determination of the DL manufacturing end point, made through the soluble solids content determination in Degree Brix, is relevant both at the beginning and at the end of manufacturing. This point indicates whether or not the product is ready to be bottled for storage and marketing. The higher the soluble solids content of the raw material, the higher the production yield, the shorter the evaporation time, and the lower the manufacturing costs (Silva et al., 2015).

Gaze et al. (2015) analyzed commercial brands of dulce de leche for moisture content, protein, fat, ash, $\mathrm{pH}$ and titratable 
acidity, mineral content (sodium, potassium, calcium, and phosphorus), colour parameters and instrumental analysis (carbohydrates content and volatile compounds), the results indicated extensive variability among all the parameters evaluated, suggesting different operational procedures in the dairy factories along the DL processing. According to legislation dulce de leche should has maximum of $30 \%$ of moisture and to achieve this value of standardization and quality control the soluble solids determination is mandatory during production (Perrone et al., 2011). In this sense, an increase of intrinsic quality of DL is related closely the standardization of operational parameters using during the manufacture (Gaze et al., 2015).

This study investigated the evaporation rates and the evaporative capacity of evaporators at atmospheric pressure (pans) during DL manufacturing.

\section{Materials and methods}

Twelve pasty DLs were produced following the traditional process proposed by Perrone et al. (2011).

The fabrications were carried out at the Federal University of Viçosa (UFV) in the Department of Food Technology - Inovaleite Platform. The DLs were processed in a double-walled stainless steel Inoxul ${ }^{\oplus}$ pan, with a capacity of $15 \mathrm{~kg}$ of milk and a stirring blade (50 rpm). First, standardized and pasteurized milk, sugar, and baking soda were placed in the pan. Next, the process of concentration of the milk was begun, with stirring until the desired soluble solids content, $69( \pm 1)^{\circ}$ Brix, and a maximum temperature of $110^{\circ} \mathrm{C}$. The cooking time of DL depends on the type of equipment used, initial soluble solids content, coloration, and desired humidity. In the present study, the manufacturing time varied from $1 \mathrm{~h}$ and $15 \mathrm{~min}$ to $1 \mathrm{~h}$ and $30 \mathrm{~min}$, with an average time of $1 \mathrm{~h}$ and $19 \mathrm{~min}$.

In all treatments, the sugar content (sucrose and glucose) was $20 \%(\mathrm{w} / \mathrm{w}$ ) of milk mass; only the proportion of these two sugars with respect to one another varied. Treatment 1 (milk $+20 \%$ sucrose +12 g bicarbonate), Treatment 2 (milk $+20 \%$ sucrose $+18 \mathrm{~g}$ bicarbonate), Treatment 3 (milk $+18 \%$ sucrose $+2 \%$ glucose +12 g bicarbonate) and Treatment 4 (milk $+18 \%$ sucrose $+2 \%$ glucose $+18 \mathrm{~g}$ bicarbonate $)$.

The experimental design consisted of four treatments in triplicate, with sample collection from the syrup and from the final product for freezing and subsequent analysis. Samples were taken at six different time points during manufacturing:(i) time point 1, syrup of the ingredients without heating; (ii) time point2, syrup with 15 minutes of heating; (iii) time point 3 , syrup with 30 minutes of heating; (iv)time point 4 , syrup with 45 minutes of heating; (v)time point5, syrup with 60 minutes of heating; and (vi)time point6, final DL. DLs were stored at room temperature for $30 \mathrm{~d}$ following manufacture, for analysis attime point7.

Quantification of soluble solids content was obtained in the present study in triplicate, by refractometry using the Reichert AR200 equipment.

The mass balance was used to determine the yield and evaporation rate, and followed the procedures proposed by Perrone et al. (2011). The determination of yield, evaporated water mass, and evaporation rate for the produced DLs was performed using Equations 1 and 2, and followed the schematization of the industrial processes presented in Figure 1.

$M L C D=\frac{[(\text { MLPproduced } * \% S L L P)+M S C]}{\% S T L C D}$

In Equation 1, MLCD = mass of product; MLP = mass of milk or standardized whey $(\mathrm{kg})$ or volume of milk or whey $(\mathrm{L}) ; \mathrm{SLLP}=$ milk solids or standard whey expressed as $(\mathrm{m} / \mathrm{m})$ or expressed as $(\mathrm{m} / \mathrm{v}) ; \mathrm{MSC}=$ mass of sucrose $(\mathrm{kg})$; and $\% S T L C D=$ percentage of total solids of the product expressed in $(\mathrm{m} / \mathrm{m})$.

$F C=\frac{T S L L C D}{T S L L}$

In Equation 2, $\mathrm{FC}=$ concentration factor; TSLLCD = lactic solids content in final product; and TSLL = lactic solids content in milk or whey. Figure 1 summarizes the process of DL production.

The soluble solids content measured at different steps in the manufacturing of the experimental DLs was analyzed using different statistical programs. The analysis of variance (ANOVA) and the test of comparison of averages were performed using the ASSISTAT program for each experiment in randomized blocks with repetitions.

The statistical analyses of the results were performed using the Microsoft Office Excel ${ }^{\triangleright}$ software system (version 2011).

\section{Results and discussion}

The manufacturing end point is determined at the end of the process to assay for whether the product is ready to be cooled and packaged. One of the easiest, most effective, and most reliable methods of assay is soluble solids determination by refractometry (Silva et al., 2015).

The descriptive analysis for the soluble solids content bound the results of the different treatments at specific times (Table 1).

The coefficient of variation and amplitude were low, which indicate a standardization and uniformity during the manufacture with respect to the former. This standardization is important to achieve, as it suggests that the DL has been subject to the same manufacturing conditions, and that the formulated product

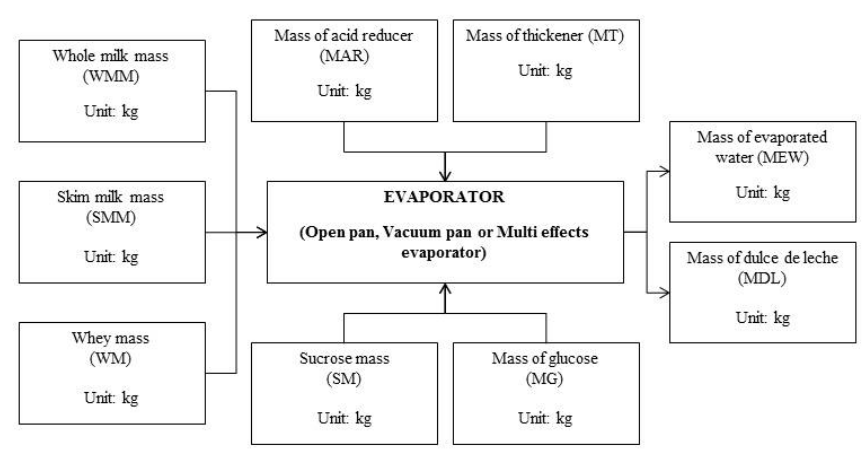

Figure 1. Schematization of DL production process from Perrone et al. (2011). 
Table 1. Descriptive statistics of the soluble solids content of experimental DLs.

\begin{tabular}{|c|c|c|c|c|c|c|c|}
\hline \multirow{2}{*}{ Descriptive statistics } & \multicolumn{7}{|c|}{ Time point $\left({ }^{*}\right)$} \\
\hline & 1 & 2 & 3 & 4 & 5 & 6 & 7 \\
\hline Mean & 25.00 & 28.34 & 33.20 & 41.35 & 55.22 & 69.82 & 68.98 \\
\hline Standard deviation & 0.74 & 0.74 & 1.88 & 5.23 & 9.24 & 0.98 & 1.15 \\
\hline $\operatorname{Max}$ & 26.26 & 29.37 & 36.80 & 51.40 & 68.97 & 71.50 & 70.30 \\
\hline Amplitude & 2.46 & 2.53 & 6.17 & 15.37 & 25.17 & 3.00 & 3.93 \\
\hline
\end{tabular}

has consistent sensorial, physicochemical, compositional, and nutritional characteristics.

Time point 1 presented the lowest ${ }^{\circ} \mathrm{Brix}$, because it corresponds to the syrup without heating. Upon the evolution of the heating, it is noticed that the average of the soluble solids content gradually increased from $25^{\circ}$ Brix to $69.82^{\circ}$ Brix.

An analysis of variance indicated that at the $1 \%$ probability level, there was no significant difference between the treatments. The soluble solids content did not change due to the type of ingredients used.

The soluble solids content differed significantly $(\mathrm{p}<0.01)$ between different time points. The concentration during the preparation of DL becomes difficult at the beginning of the heat treatment, as there is a large amount of water to be evaporated. Likewise, as the end of the preparation approaches, evaporation becomes difficult as a result of the high boiling point of the product at this stage. These two phenomena explain why soluble solids content increases relatively slowly at the beginning and at the end of the DL manufacturing process (Figure 2).

By using the regression analysis, it was possible to follow the evolution of the soluble solids content during the manufacture and after $30 \mathrm{~d}$ of storage at room temperature. Figure 3 present the results for the soluble solids content $\left({ }^{\circ}\right.$ Brix), and the statistical model for the four different treatments performed.

The mathematical model that best fit the data was the polynomial. Samples from the four treatments invariably presented an increase in the concentration of soluble solids content over time.

During the manufacture of dulce de leche, milk evaporation depends on the external pressure, hydrostatic principle, heat load, and soluble solids content. At the beginning of the process, the syrup formed by the mixture of ingredients has a high amount of water, which allows for relatively rapid evaporation. Over the course of heating, viscosity and concentration of total solids increases (Perrone et al., 2011).

The findings for the soluble solids content in this work can inform the heat treatment and storage of the DLs. Soluble solid content can facilitate manufacturing control, determination of the manufacturing end point, assurance of product homogeneity, and shelf life extension.

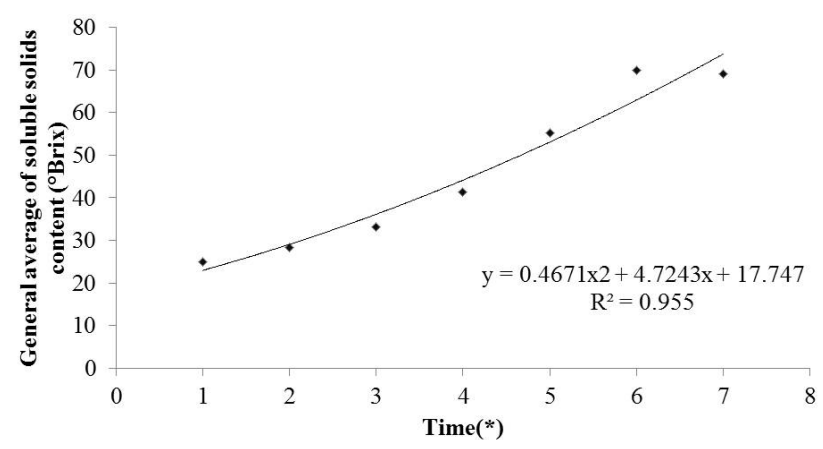

Figure 2. Polynomial regression of the behavior of the general mean of the soluble solids content during the manufacture of the experimental DL during heat treatment and storage; prepared by the author. $\left.{ }^{*}\right)$ Time point 1: without heating; Time point 2: $15 \mathrm{~min}$;; Time point $3=30 \mathrm{~min}$;; Time point $4=45 \mathrm{~min}$.; Time point $5=60 \mathrm{~min}$.; Time point $6=$ Final product; Time point $7=30$-day stored product.

Figure 4 shows the evaporated water mass over different time points in the DL manufacturing process.

Due to the characteristics of the curve, the quadratic mathematical model was the one that best adjusted for the evaporated water mass rate.

Figure 5 shows the percentage of water evaporated during manufacturing as a function of the time the product was exposed to the heat treatment.

Manufacturers of DL seek an ideal balance of color, manufacturing time, pot temperature, and product formulation. We assume that during the preparation of the experimental DLs, the temperature in the pan and composition remain constant. In case of using pots of different construction specifications, of varying load capacity, or even of varying production loads, at industrial scale, the application of the above mathematical models will yield the same rate of evaporation and the same percentage of evaporated water.

The production of a DL equivalent to that formulated in this study can be achieved from the repetition of the curve shown in Figure 4. If the same percentage of evaporated water is reached at each stage, even under different experimental or manufacturing conditions, the resulting DL will tend to present 

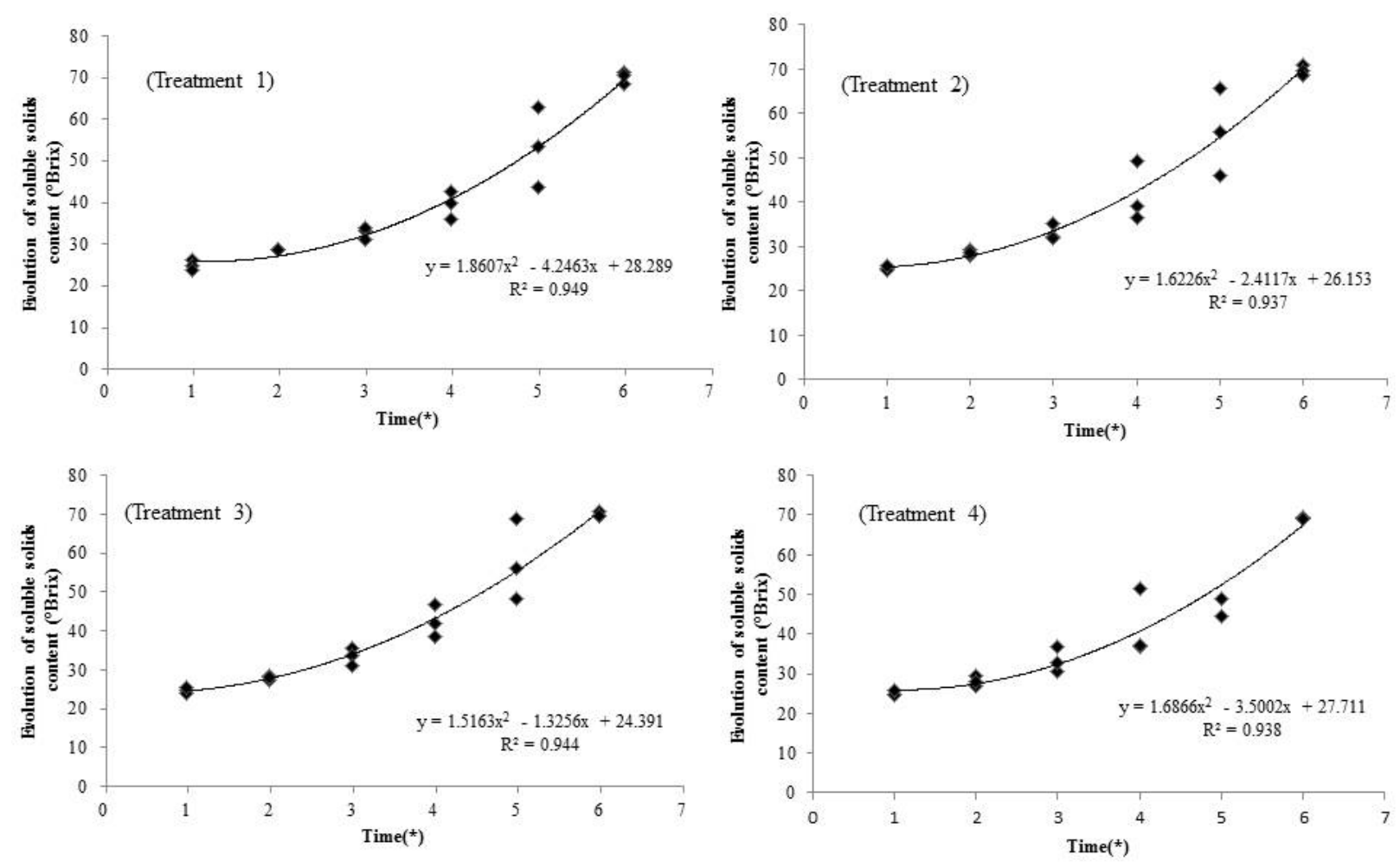

Figure 3. Polynomial regression of the behavior of soluble solids content, in treatment 1,2,3 and 4 in the experimental DLs during the heat treatment, and storage; prepared by the author. $\left.{ }^{*}\right)$ Time point 1 : without heating; Time point $2: 15 \mathrm{~min}$.; Time point $3=30 \mathrm{~min}$.; Time point $4=45 \mathrm{~min}$.; Time point $5=60 \mathrm{~min}$.; Time point $6=$ Final product; Time point $7=30$-day stored product.

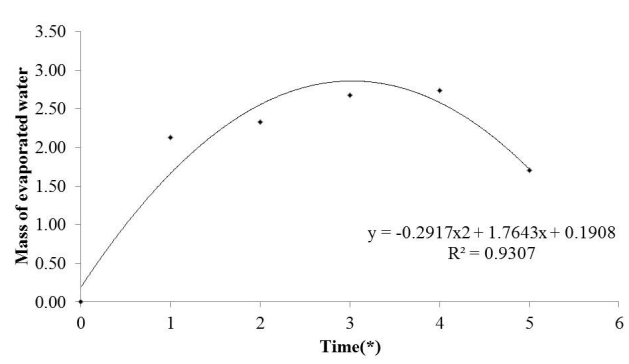

Figure 4. Evaporated water mass $(\mathrm{kg})$ as a function of the DL manufacture time point, starting from $18.02 \mathrm{~kg}$ of syrup; prepared by the author. $\left({ }^{*}\right)$ Time point 1: without heating; Time point 2 : $15 \mathrm{~min}$.; Time point $3=30 \mathrm{~min}$.; Time point $4=45 \mathrm{~min}$.; Time point $5=60 \mathrm{~min}$.; Time point $6=$ Final product; Time point $7=30$-day stored product.

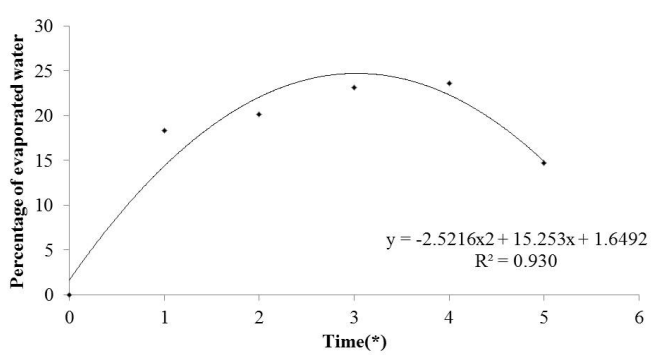

Figure 5. Percentage of evaporated water as a function of the DL manufacture time point, starting from $18.02 \mathrm{~kg}$ of syrup; prepared by the author. $\left(^{*}\right)$ Time point 1: without heating; Time point 2: $15 \mathrm{~min}$.; Time point $3=30 \mathrm{~min}$.; Time point $4=45 \mathrm{~min}$.; Time point $5=60 \mathrm{~min}$.; Time point $6=$ Final product; Time point $7=30$-day stored product. very similar characteristics to those of the DL obtained by this study, regardless of the volume, pot type, or formulated product composition. This same percentage of evaporated water can be achieved by controlling the soluble solid content and the rate of water evaporation during manufacture.

\section{Conclusion}

Soluble solids content gradually increased throughout the DL production because of the concentration that the ingredients were subject to during heating. Soluble solids content is a metric used to assure that a DL product meets minimum legislation requirements. The evaporated water mass and its respective equation, obtained using polynomial regression, provide a general model for DL production, and exhibit the same characteristics as the experimental product of this work, regardless of volume, equipment type, or composition.

\section{References}

Arena, S., Renzone, G., D’Ambrosio, C., Salzano, A. M., \& Scaloni, A. (2017). Dairy products and the Maillard reaction: A promising future for extensive food characterization by integrated proteomics studies. Food Chemistry, 219, 477-489. http://dx.doi.org/10.1016/j. foodchem.2016.09.165. PMid:27765254.

Gaze, L. V., Costa, M. P., Monteiro, M. L., Lavorato, J. A., Conte, C. A. Jr., Raices, R. S., Cruz, A. G., \& Freitas, M. Q. (2015). Dulce de Leche, a typical product of Latin America: characterisation by physicochemical, optical and instrumental methods. Food Chemistry, 169, 471-477. http://dx.doi.org/10.1016/j.foodchem.2014.08.017. PMid:25236253. 
Perrone, I. T. (2007). Tecnologia para a fabricação de doce de leite. Revista do Instituto de Latícinios Cândido Tostes, 62, 43-49.

Perrone, I. T., Stephani, R., \& Neves, B. S. (2011). Doce de leite: aspectos tecnológicos. São Paulo: Livraria Varela.

Schuck, P., Jeantet, R., Bhandari, B., Chen, X. D., Perrone, Í. T., Carvalho, A. F., Fenelon, M., \& Kelly, P. (2016). Recent advances in spray drying relevant to the dairy industry: a comprehensive critical review. Drying Technology, 34(15), 1773-1790. http://dx.doi.org/10.1080/ 07373937.2016.1233114.

Silva, F. L., Ferreira, H. A. L., Carvalho, A. F., \& Perrone, I. T. (2013). Efeito do soro de leite no processo de concentração do doce de leite pastoso. Revista do Instituto de Latícinios Cândido Tostes, 68(394), 20-24.

Silva, F. L., Ferreira, H. A. L., Souza, A. B., Almeida, D. F., Stephani, R., Pirozi, M. R., Carvalho, A. F., \&Perrone, Í. T. (2015). Production of dulce de leche: the effect of starch addition. Lebensmittel-Wissenschaft + Technologie, 62(1), 417-423. http://dx.doi.org/10.1016/j.lwt.2014.10.062.

Silveira, A. C. P., Carvalho, A. F., Perrone, Í. T., Fromont, L., Méjean, S., Tanguy, G., Jeantet, R., \& Schuck, P. (2013). Pilot-scale investigation of effectiveness of evaporation of skim milk compared to water. Dairy Science \& Technology, 93(4-5), 537-549. http://dx.doi.org/10.1007/ s13594-013-0138-1.

Silveira, A. C. P., Tanguy, G., Perrone, Í. T., Jeantet, R., Ducept, F., Carvalho, A. F., \& Schuck, P. (2015). Flow regime assessment in falling film evaporators using residence time distribution functions. Journal of Food Engineering, 160, 65-76. http://dx.doi.org/10.1016/j. jfoodeng.2015.03.016.

Souza, A. B., Costa, L. C. G. Jr, Stephani, R., Oliveira, M. A. L., Perrone, Í. T., \& Costa, R. G. B. (2015). Evaluation of the viscosity profile obtained for dispersions containing different proportions of milk protein concentrate/whey protein concentrate during simulated conditions of thermal processing. Lebensmittel-Wissenschaft + Technologie, 64(2), 536-539. http://dx.doi.org/10.1016/j.lwt.2015.05.058.

Stephani, R., \& Perrone, Í. T. (2012). Balanço de massa aplicado a tecnologia de produção do leite condensado: considerações teóricas. Revista do Instituto de Latícinios Cândido Tostes, 67(387), 49-56. http://dx.doi.org/10.5935/2238-6416.20120049.

Stephani, R., Souza, A. B., Oliveira, M. A. L., Perrone, Í. T., Carvalho, A. F., \& Oliveira, L. F. C. (2015). Evaluation of the synergistic effects of milk proteins in a rapid viscosity analyzer. Journal of Dairy Science, 98(12), 8333-8347. http://dx.doi.org/10.3168/jds.20159300. PMid:26409966.

Tanguy, G., Siddique, F., Beaucher, E., Santellani, A. C., Schuck, P., \& Gaucheron, F. (2016). Calcium phosphate precipitation during concentration by vacuum evaporation of milk ultrafiltrate and microfiltrate. Lebensmittel-Wissenschaft + Technologie, 69, 554-562. http://dx.doi.org/10.1016/j.lwt.2016.02.023. 